\title{
From platform to basin: the evolution of a Paleocene carbonate margin (Eastern Desert, Egypt)
}

Received: 28 February 2002 / Accepted: 6 March 2003 / Published online: 5 August 2003

(C) Springer-Verlag 2003

\begin{abstract}
In this study, progradation and the subsequent retrogradation of a late Paleocene isolated carbonate platform (Galala Mountains, Eastern Desert, Egypt) is demonstrated by variations of distinct facies associations from the platform margin in the north to the hemipelagic basin in the south. A combination of a sea-level drop and tectonic uplift at around $59 \mathrm{Ma}$ (calcareous nannofossil biozone NP5) favored the initiation of the carbonate platform. From this time onwards, the facies distribution along the platform-basin transect can be subdivided into five facies belts comprising nine different facies associations. Their internal relationships and specific depositional settings are strongly coupled with the Maastrichtian-Paleocene seafloor topography, which resulted from local tectonic movements. Patch reefs and reef debris were deposited at the platform margin and the horizontally bedded limestones on the upper slope. Slumps and debris flows were stored on the lower slope. In the subhorizontal toe-of-slope facies belt, mass-flow deposits pass into calciturbidites. Further southwards in the basin, only hemipelagic marls were deposited. Between 59 and 56.2 Ma (NP5-NP8), the overall carbonate platform system prograded in several pulses. Distinct changes in facies associations from 56.2 to
\end{abstract}

C. Scheibner · R. P. Speijer · J. Kuss

Universität Bremen,

FB5, P.O. Box 330440, 28334 Bremen, Germany

\section{J. J. G. Reijmer}

GEOMAR, Forschungszentrum für Marine Geowissenschaften, Wischhofstr. 1-3, 24148 Kiel, Germany

\author{
A. M. Marzouk \\ Geology Department, Faculty of Science, \\ Tanta University, \\ 31527 Tanta, Egypt \\ Present address: \\ Universität Potsdam, Institut für Geowissenschaften, \\ PF 601553, 14415 Potsdam, Germany \\ e-mail: scheibner@geo.uni-potsdam.de \\ Tel.: +49-331-9775071 \\ Fax: +49-331-9775060
}

55.5 Ma (NP9) resulted from rotational block movements. They led to increased subsidence at the platform margin and a coeval uplift in the toe-of-slope areas. This resulted in the retrogradation of the carbonate platform. Furthermore the patch-reef and reef-debris facies associations were substituted by the larger foraminifera shoal association. The retrogradation is also documented by a significant decrease in slump and debris-flow deposits on the slope and calciturbidites at the toe of slope.

Keywords Egypt - Paleocene - Tectonics - Carbonate slope deposits $\cdot$ Mass-flow deposits

\section{Introduction}

In recent years, slope processes of rimmed carbonate platforms have been studied intensively. Various studies focused on the overall geometry of seismic sections of the slopes regardless of the biotic content. They subdivided their profiles into linear, exponential and sigmoidal slope profiles, generally concluding that most slope profiles have a sigmoidal slope curvature (Adams et al. 1998; Adams and Schlager 2000). A genetic approach to classifying carbonate margins was presented by Pomar (2001). This genetic approach considers the variability of depositional profiles, from rimmed carbonate platforms to homoclinal ramps, as a function of the type of sediment, especially in terms of bioclast contribution to the sediment, the location of sediment production, and the hydraulic energy. Drzewiecki and Simó (2002) and Scheibner et al. (2000) concentrated on the depositional processes and triggering mechanisms of debris flows whilst Kenter and Schlager (1989), and Kenter (1990) focused on the relationship between sediment composition and angle of repose. Others, e.g., Kenter and Campbell (1991), have described the facies distribution along a rimmed platform margin for the early Jurassic (High Atlas, Morocco). Toe-of-slope geometries were described by Bosellini (1984), Stafleu and Schlager (1995), and recently by Blomeier and Reijmer (2002), 
whilst Keim and Schlager (1999) and Blendinger (2001) concentrated on the production potential of carbonate slopes, as well as the role of microbial processes in stabilizing upper slope environments.

A summary of recent literature on the factors controlling progradational and retrogradational patterns of carbonate platforms is given in Reijmer (1998). The most important factor controlling stratal patterns and facies variations on platforms, is the available accommodation space that in turn is dependent on, e.g., the platform configuration, basin depth and eustatic sea-level variations. Oscillating sea level may not always be the cause of variations in stacking patterns in carbonate platforms as climatic factors, changing transport rate, and productivity are also capable of producing similar stacking patterns (Burgess 2001). Additional factors controlling the evolution of a platform margin are tectonics (Read 1985).

Slope processes and slope facies studied in tectonicinfluenced environments may be dominated by seismites (Plaziat and Purser 1998; Purser and Plaziat 1998), whereas Beattie and Dade (1996) suggest that the rate of turbidite emplacement may be used as important constraints on paleoseismicity. Research on turbidite emplacement in the Horseshoe abyssal plain (Iberian margin), however, showed the low impact of tectonic activity on turbidite initiation (Lebreiro et al. 1997) because one of the largest earthquakes recorded in human history (Lisbon in 1755) only resulted in the production of a thin turbidite layer. In addition, the timing of turbidite emplacement around Pedro Bank (Caribbean) suggests that loading and reloading processes of upper-slope sediments during transgressions and regressions may be another triggering mechanism for gravity flows other than tectonic activity (Andresen et al. 2003). The two factors responsible for initiation of mass transports are strength reduction and stress increase, which can be changed by sedimentary loading, pressure from surface waves during storms, sea-level changes, pore-gas generation, localized seafloor erosion and tectonics (Prior and Coleman 1984).

In the study area of the Southern Galala (Gulf of Suez, Egypt; Fig. 1), large masses of shallow-marine sediments (siliciclastic marls and limestones) were shed from the Northern Galala/Wadi Araba High southwards during the late Campanian-Maastrichtian. These sediments accumulated on the slope of a carbonate platform, as can be found within a narrow belt at the northern rim of the Southern Galala (sections A1 and A5 around St. Anthony; Fig. 1). The late Cretaceous units further north were subsequently eroded, hampering the reconstruction of the type of platform that existed in this time period. Calculations of slope angles suggest it was a rimmed platform (Scheibner et al. 2001b, 2003). Further south (sections S1-9 around St. Paul, Fig. 1) basinal chalks prevail (Scheibner et al. 2001a). Due to the southward progradation of the carbonate platform and the better exposure of this platform, subsequent Paleogene deposits have a much wider aerial distribution than their upper Cretaceous counterparts (Kuss et al. 2000b, Scheibner et al. 2001a). Based on the observed broad depositional belt of Pale- ocene slope deposits, a gentler inclined slope can be assumed for the late Paleocene (Kulbrok 1996; Kuss et al. 2000b). A segment of this belt was investigated in the vicinity of St. Paul (section S1-8; Fig. 1). It shows a continuous 360-m-wide outcrop of mass-flow deposits (Scheibner et al. 2000), in which the internal lateral transitions of the different types of mass-flow deposits were studied (approximately perpendicular to the former transport direction). Scheibner et al. (2000) postulated several progradational phases for the late Paleocene, starting at $59 \mathrm{Ma}$, due to existence of different generations of mass-flow deposits. Microfacies analysis of the debris flows provided evidence for a change in their origin from a more distal setting to a more proximal setting. This change is associated with a change in biota distribution. While coralline red algae prevailed in the SelandianThanetian debris flows, nummulitids (Miscellanea spp., Ranikothalia spp., and Operculina spp.) dominated the late Thanetian deposits.

In this paper, we demonstrate the role of tectonic processes on the distribution and development of facies associations and facies belts along a $30-\mathrm{km}$-long Paleocene carbonate platform-to-basin-transition in the Galala Mountains, Egypt. These processes also controlled the Paleocene evolution from a progradational to a retrogradational platform margin.

\section{Material and methods}

The study area extends from the northern rim of the Southern Galala Mountains (western side of the Gulf of Suez) approximately $30 \mathrm{~km}$ southwards to the Bir Dakhl area (Fig. 1). Twenty-one Paleogene sections were investigated in detail (Fig. 1). Eight of these sections were selected for lithostratigraphic correlation along a transect from the platform in the north to the basin in the south (Fig. 2). Section A5 is located at the northern rim of the Southern Galala, and sections K3 and K2 are located in the northern part of Wadi Askhar that runs perpendicular to the strike of the former platform. Sections D5, D6, D2 and D4 lie south of the Southern Galala. The other thirteen sections (B2, B3, A1, A1b, K4, K5, S9, S1-8, D7, D8, D3, T1, T2) provide additional biostratigraphic and paleoenvironmental information. Some of these sections (A1, S9, S1-8, D3, T1 and T2) have been described in detail in Scheibner et al. (2000, 2001a, 2001b).

Thin-section studies of Paleocene-lower Eocene limestones are complemented by investigations on washed residues of marl samples. Sample spacing varied throughout the individual sections from 30 to $100 \mathrm{~cm}$ within shaley and marly sediments (Fig. 2), to $50 \mathrm{~cm}$ to $5 \mathrm{~m}$ in more calcareous and chalky sediments. Calcareous nannoplankton and planktic foraminifera provided the biostratigraphic framework.

The natural $\gamma$-ray values of each carbonate bed of the vertical sections were measured (Geometrix Exploranium GR-410/GPX-21; 2 min measuring time). It provided an additional tool for tracing the different sediment packages 
Fig. 1 Satellite image of the Paleocene sections in the Southern Galala Mountains, Eastern Desert, Egypt. Lower inset: Syrian arc structures in Egypt, Sinai and Israel. Upper inset: The Galala Mountains on the western side of the Gulf of Suez. The Northern Galala and the Southern Galala are divided by the Wadi Araba. Sections T1 and T2 of Fig. 3 lie south of the area that is covered by the satellite image (rectangle). The strike directions of the Wadi Araba Fault (related to Mesozoic-Paleogene tectonics) and the Gulf of Suez Faults (related to the Miocene opening of the Gulf) lie perpendicular to each other. Satellite image courtesy of http://zulu.ssc.nasa.gov/ mrsid/

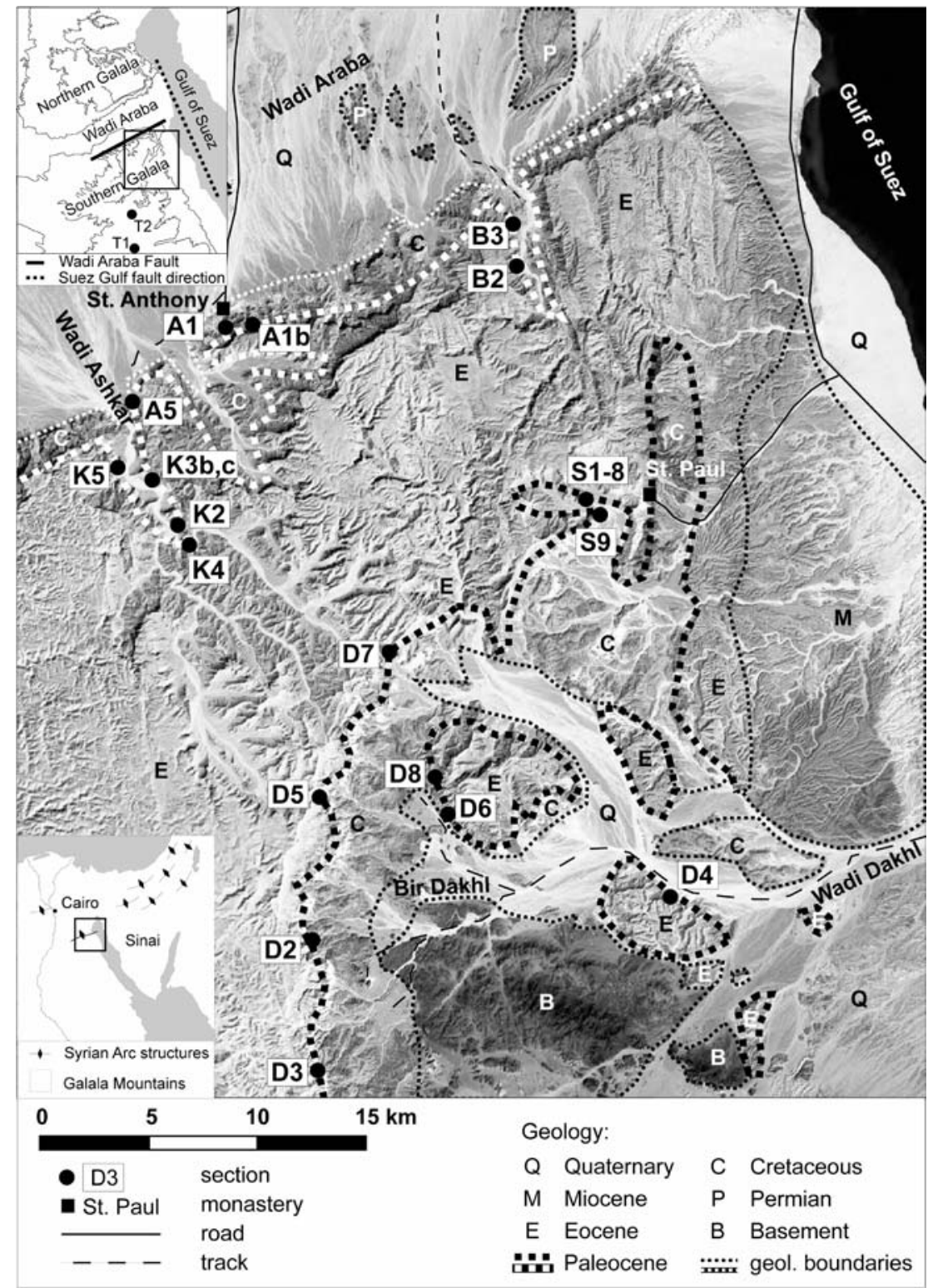

along the platform-to-basin transect, e.g., the Maastrichtian-lower Paleocene sediments on the slope sections. These slope sediments are characterized by high phosphatic content and thus, high $\gamma$-ray values. Two synthetic $\gamma$-ray plots are plotted for the proximal and distal parts of the platform (Fig. 3).

\section{Geological setting}

General

The Galala Mountains in the Eastern Desert west of the Gulf of Suez, represent a southern branch of the Syrian Arc fold belt, called the Northern Galala/Wadi Araba High (NGWA; Kuss et al. 2000b; Fig. 1, lower inset). The Syrian Arc System was formed during the collision between the African and European plates, starting in early Turonian times. A dextral transpressive reactivating of Mesozoic half-grabens resulted in a series of inverted, uplifted and folded grabens (e.g., Moustafa and Khalil 1995). The NGWA High is separated by east-northeasttrending faults (Bandel and Kuss 1987) that run perpendicular to the younger Gulf of Suez faults, which resulted from the Miocene opening of the Gulf. Hussein and AbdAllah (2001) interpreted the NGWA High as an overturned anticline. The most prominent fault in this area is the Wadi Araba fault at the northern rim of the Southern Galala (Schütz 1994; Fig. 1, upper inset).

On the NGWA High a mixed carbonate platform evolved during the late Campanian to Eocene. Similar to other Syrian Arc Highs on the Sinai Peninsula, the Galala mountain range strikes in WSW-ENE direction (Kuss et al. 2000a). The investigated sections follow a paleogeo- 

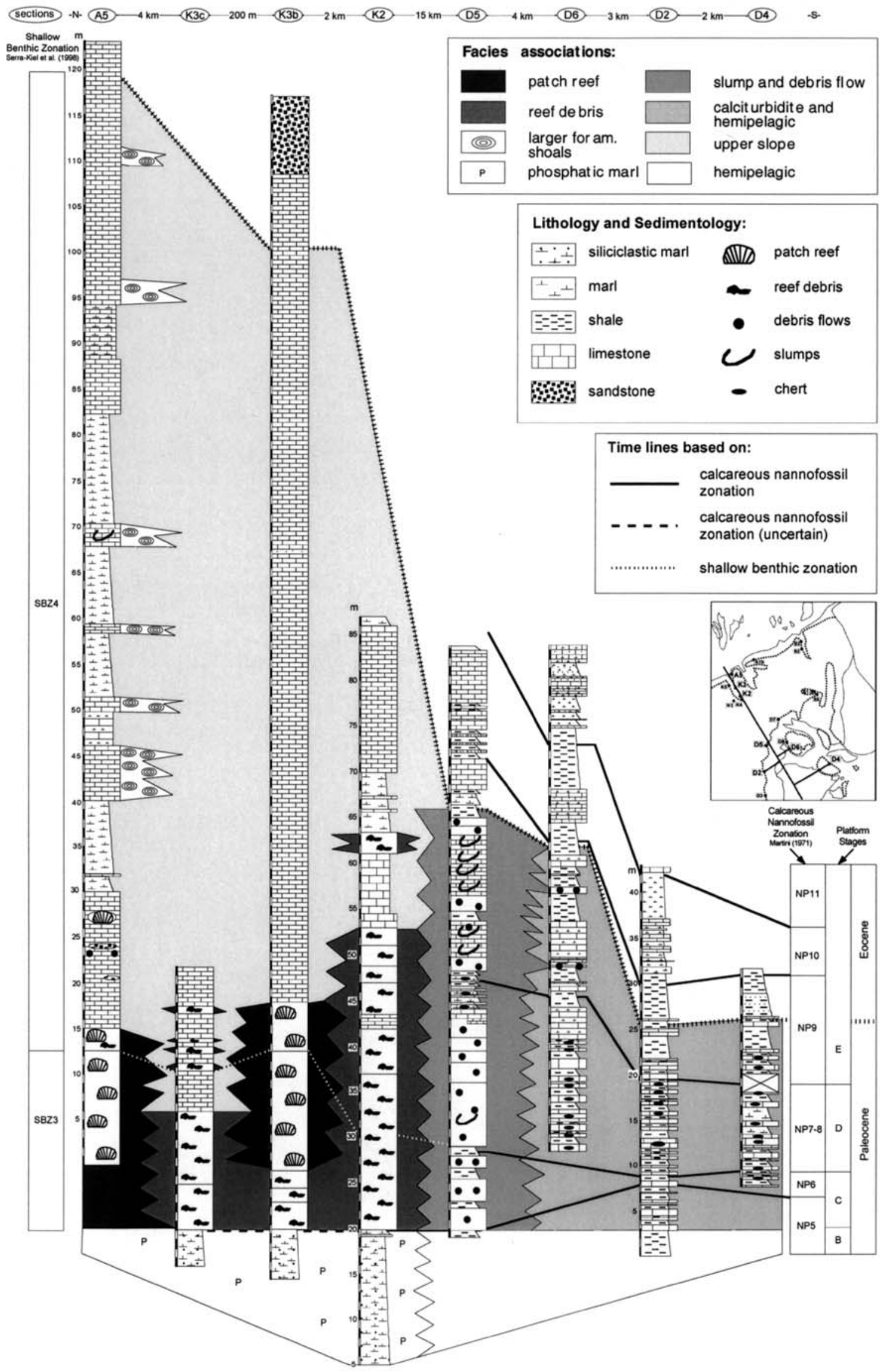

Fig. 2 Lithostratigraphic correlation and distribution of facies associations along the platform-basin transect. The profiles are projected onto a profile line orientated perpendicular to the former strike of the carbonate platform (see inset). The siliciclastic facies association is not shown because of its limited occurrence 
Fig. 3 Biostratigraphy, lithology and formations of Maastrichtian-Eocene sections from the Eastern Desert, Egypt. The biozonations of planktic foraminifera ( $P$ zones $)$, calcareous nannoplankton (NP zones for Paleogene and $C C$ zones for Maastrichtian) and shallow benthic foraminifera $(S B Z)$ are listed. The $S B Z$ is slightly modified (termination of SBZ4 is contemporaneously with the Paleocene/Eocene boundary). The gray band reflects the current opinion on the position of the Thanetian-Ypresian boundary (Berggren et al. 1995). The sections are mainly oriented $\mathrm{N}$ $S$ with the exception of sections Wadi B2 and Wadi B3. The 2D profile on the top shows the paleogeographic position and facies belt of each individual section. Sections $T 1$ and $T 2$ represent the basin facies belt and are taken from Scheibner et al. (2001a). Two synthetic $\gamma$-ray profiles are shown for the proximal and distal areas

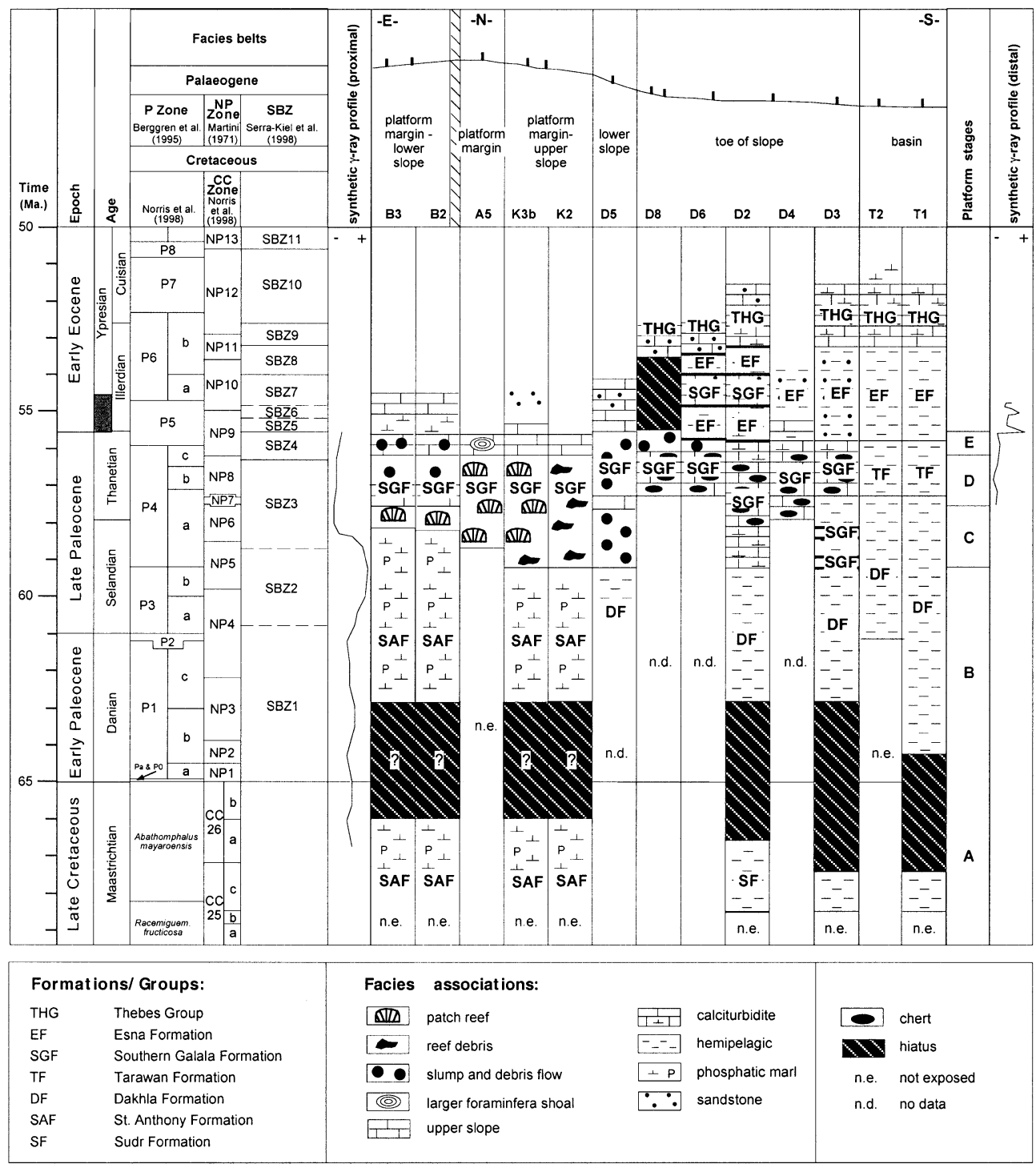

graphical transect running perpendicular to the former strike, ranging from the platform in the north to the basin in the south (Figs. 2 and 3).

\section{Paleoenvironment and lithostratigraphy}

The late Campanian-early Eocene paleogeographic setting of the Galala area can be subdivided into three different areas (Scheibner et al. 2001a). The northern realm is characterized by erosion or non-deposition resulting mostly from the uplift of the northern Galala/ Wadi Araba High (NGWA High). Shallow-marine carbonate platform and slope deposits of the late Campanian-Maastrichtian, and the Paleocene-lower Eocene represent the second area and occur north and south of the NGWA High. The southern and third area consists of Campanian-Maastrichtian basinal chalks and Paleocenelower Eocene marls and shales (Scheibner et al. 2001a). The distribution and lateral facies changes between these three areas reflect changing basin morphology and progradation of the carbonate platform triggered by sealevel changes and tectonic processes (Scheibner et al. 2001a).

Shallow-marine carbonates and siliciclastics of the St. Anthony Formation were deposited during the late Campanian to Paleocene and are only exposed in a narrow east-west trending belt at the northern rim of the Southern Galala (Scheibner et al. 2001a, 2001b; Fig. 3). Basinal sediments of the Sudr Formation accumulated contemporaneously $14 \mathrm{~km}$ to the south at St. Paul (Fig. 3). The lateral transition between the shallow-marine St. Anthony Formation and the basinal Sudr Formation is not exposed. In contrast, the interfingering between Paleocene-lower Eocene shallow-marine limestones of the Southern Galala Formation and deeper marine deposits of the basinal Dakhla and Esna Formations are well-exposed near Bir Dakhl (D2, D3, D4, D5, D6 and D8; Figs. 1, 2, $3)$. The five facies belts incorporated in the PaleoceneEocene formations are all clearly separated laterally, and 
gradual transitions were found in the field from the lower slope to toe-of-slope to the basin facies belts. No distinct marker beds or erosional surfaces were found along the entire transect. The biostratigraphic correlation from platform margin to toe-of-slope is based on larger foraminifera and calcareous nannoplankton. Additional data came from $\gamma$-ray profiles and the varying biotic composition of the facies belts. For example, it is possible to correlate platform margin deposits with lower slope deposits by the abundance of corals that are present only in the older deposits of the Southern Galala Formation (Fig. 3).

The chalky and marly sediments of the basin facies belt yield rich and diverse planktonic and benthic foraminiferal assemblages. The former indicate open marine conditions and good connections to the Tethys ocean (Scheibner et al. 2003). Analysis of the latter is widely used as a powerful tool to estimate depositional depths (e.g., Culver 1993). In sections D6 and D8, we observed a middle Thanetian (57.5-56.2 Ma; NP7/8) benthic assemblage consisting of a mixture of Midway and Velasco-type taxa (e.g., Speijer 1994) indicating depositional depths of about 400-500 m. Upper Thanetian (56.2-55.5 Ma; NP9) benthic assemblages entirely composed of Midway-type taxa, as also observed in the southern Nile valley (Speijer and Schmitz 1998), indicate shallower depositional depths of about $200 \mathrm{~m}$. For a more detailed description of the lithostratigraphic units, formations and paleogeography the reader is referred to Scheibner et al. (2001a, 2003).

\section{Maastrichtian to Paleocene slope evolution}

Calculated slope geometries for the Maastrichtian (69.4$67.2 \mathrm{Ma}$ ) asymmetrical carbonate platform margin of the Southern Galala are based on the initial structural topography, sedimentary patterns, and paleobathymetric calculations using smaller benthic foraminifera and thickness variations of the rock units (Scheibner et al. 2001b). These tools form the base for paleobathymetric calculations for the individual sections of the slope and basin. In combination with simple trigonometry, the angle of repose was calculated using different models (Scheibner et al. 2001b). A model with an asymmetrical platform margin was chosen because it fits best with the geological data. The asymmetrical platform margin comprises a rimmed platform in the southeast and a ramp in the southwest. The rimmed platform can be subdivided into a gentle upper slope $\left(<1^{\circ}\right)$ and a steep lower slope $\left(5-8^{\circ}\right)$. On the ramp, the angle of repose is less than $0.1^{\circ}$ (Scheibner et al. 2001b). The relatively steep, lower slope system of the rimmed platform strikes in an ENE-WSW direction and forms a narrow belt of Campanian to Maastrichtian carbonate platform-slope sediments. The rimmed platform persists until at least the Selandian (59 Ma, Berggren et al. 1995), and is documented by relatively high slope angles of $6^{\circ}$ (Scheibner et al. 2003).

\section{Biostratigraphy}

The biostratigraphic scheme uses the nannoplankton biozonation (NP-Zones) of Martini (1971), planktic foraminifera biozones of Berggren et al. (P-Zones; 1995, 2000); and shallow benthic foraminifera biozones (SBZ) of Serra-Kiel et al. (1998; Fig. 3). The absolute time scale is adopted from Berggren et al. (1995). The studied Paleocene sediments range in age from 6555.5 Ma (NP1-NP9; SBZ1-SBZ4). The main study interval starts at $59 \mathrm{Ma}$ (within the upper part of NP5; SBZ3-SBZ4). The Paleocene-Eocene boundary is located in our study at $55.5 \mathrm{Ma}$ (within biozone NP9 and between SBZ4 and SBZ5). Detailed biostratigraphic and paleoenvironmental information on the calcareous nannoplankton and planktic foraminifera can be found in Fig. 3 as well as in Scheibner et al. (2001a) and Marzouk and Scheibner (2003).

\section{Facies belts and facies associations}

The following five Paleocene facies belts can be distinguished (Fig. 3): (1) platform margin, (2) upper slope, (3) lower slope, (4) toe of slope, and (5) basin. They reflect an overall paleobathymetric trend from the platform in the north to the basin in the south and are composed of nine facies associations. These facies associations comprise different microfacies types with a genetic relationship. In this study we focus on this genetic relationship and refrain from listing all individual microfacies types. So, the five facies belts are comprised of the following nine facies associations that can be subdivided into five autochthonous subgroups: (1) patch reef, (2) upper slope, (3) larger foraminifera shoal, (4) phosphatic marl, (5) and hemipelagic marl; and four allochthonous subgroups: (1) siliciclastic, (2) reef debris, (3) debris flow, and (4) calciturbidite.

Autochthonous facies associations

\section{Patch-reef association}

The patch-reef association (Figs. 4, 5a, b) consists of an autochthonous and a parautochthonous facies. Both facies types crop out at the northern rim of the Southern Galala (St. Anthony area; Fig. 1), in the northern parts of the Wadi Askhar (sections K2, K3 and K5; Fig. 1) and in sections B2 and B3 (Fig. 1). In the St. Anthony area, the individual patch reefs form up to 25-m-high, lenticularshaped massive carbonate bodies in which the different generations of partially overlapping patch reefs that form nearly vertical cliffs in the recent topography, can be identified. Reef debris, debris flows and planar-bedded sediments are intercalated with the individual patch reefs. In contrast to allochthonous facies associations, 7 and 8 described later have been transported across large distances. The parautochthonous sediments in Fig. 4 are 
Fig. 4 Facies distribution along the platform-basin transect. The basin facies belt is not represented because it lies south of the toe-of-slope facies belt. The siliciclastic facies association is not shown because of its limited occurrence throughout the transect. Two different platform basin transitions are indicated: one for the Maastrichtian-upper Paleocene and a second for the upper Paleocene. Below The distribution of selected components and lithologies for the Paleocene is shown
N

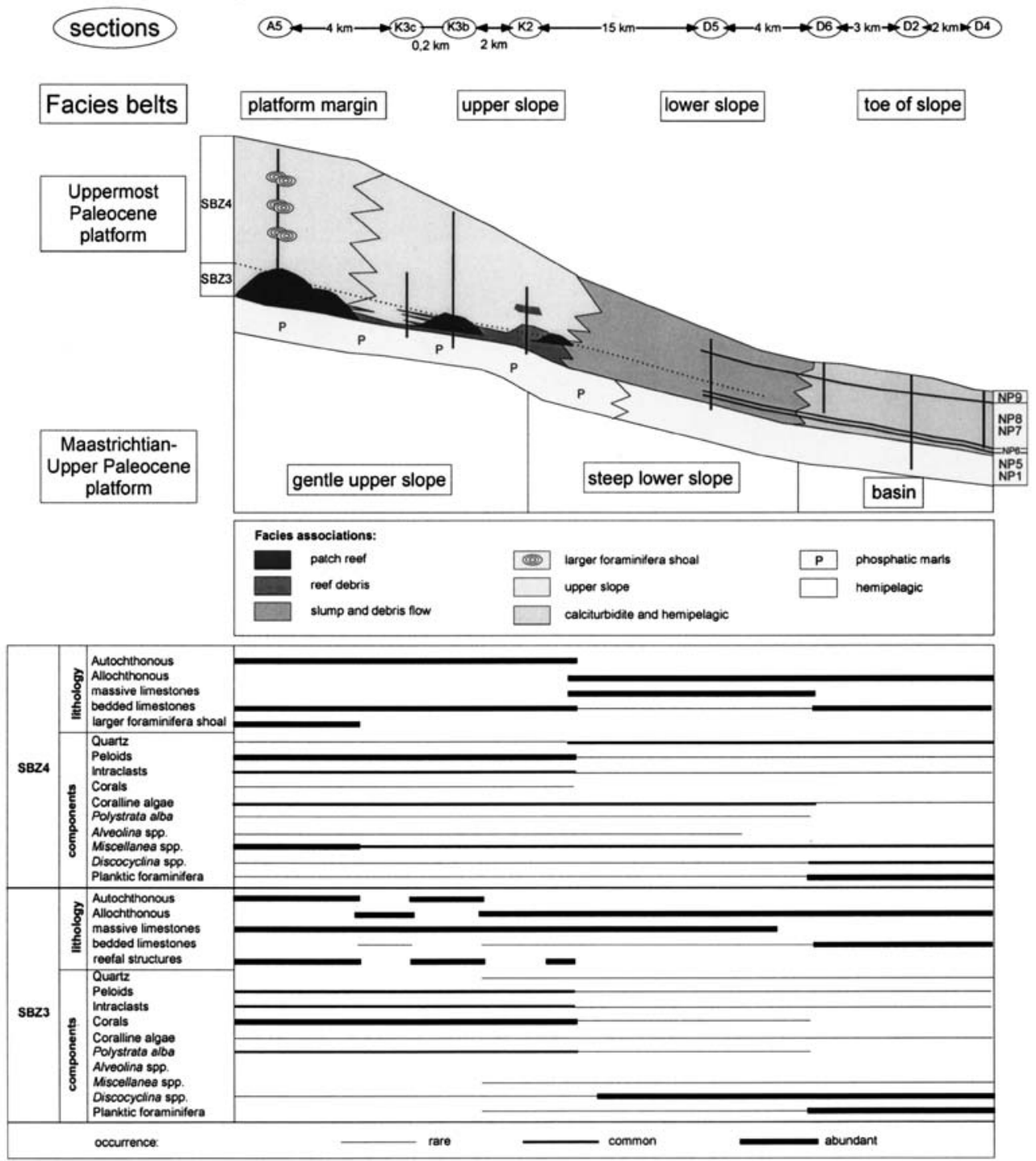

more or less reworked at the site of their original deposition. About $7 \mathrm{~km}$ southwards in the Wadi Askhar (section K3; Fig. 5a) the multiple upper Paleocene patchreef occurrences with heights of $25 \mathrm{~m}$ are reduced to a single patch-reef unit growing on top of a massive reefdebris bed.

The massive patch reefs show no internal stratification and are often strongly diagenetically altered, sometimes even into pure white dolomitic chalks in which no allochems are identifiable in outcrop. In the thin section, remnants of corals are visible. In the case of dolomitization, these chalks can be attributed to the patch-reef association only by their external lenticular shape and their massive appearance. Dendroid, meandroid and cerioid corals are the dominant components of this facies association (Fig. 5b). In the autochthonous parts of the bioherms, the dendroid corals are enclosed in a micritic matrix. Other components include encrusting coralline red algae such as Archeolithothamnium spp. or Polystrata alba and gastropods.

The parautochthonous parts of the patch reefs are also deposited in the lenticular shaped bodies and are dominated by fragments or broken corals. Additional, rare larger foraminifera such as Discocyclina spp. or rotaliids occur in the parautochthonous parts. Glomalveolina spp. is found only in the uppermost parts of the patch reefs. Non-skeletal grains present in the parautochthonous parts include intraclasts and peloids whilst quartz grains and planktic foraminifera are absent. The patch-reef association is characteristic in the older deposits in the platform margin facies belt.

\section{Upper slope association}

The upper slope association (Figs. 4, 5a) can be subdivided into two subgroups and occurs in sections B2 and 


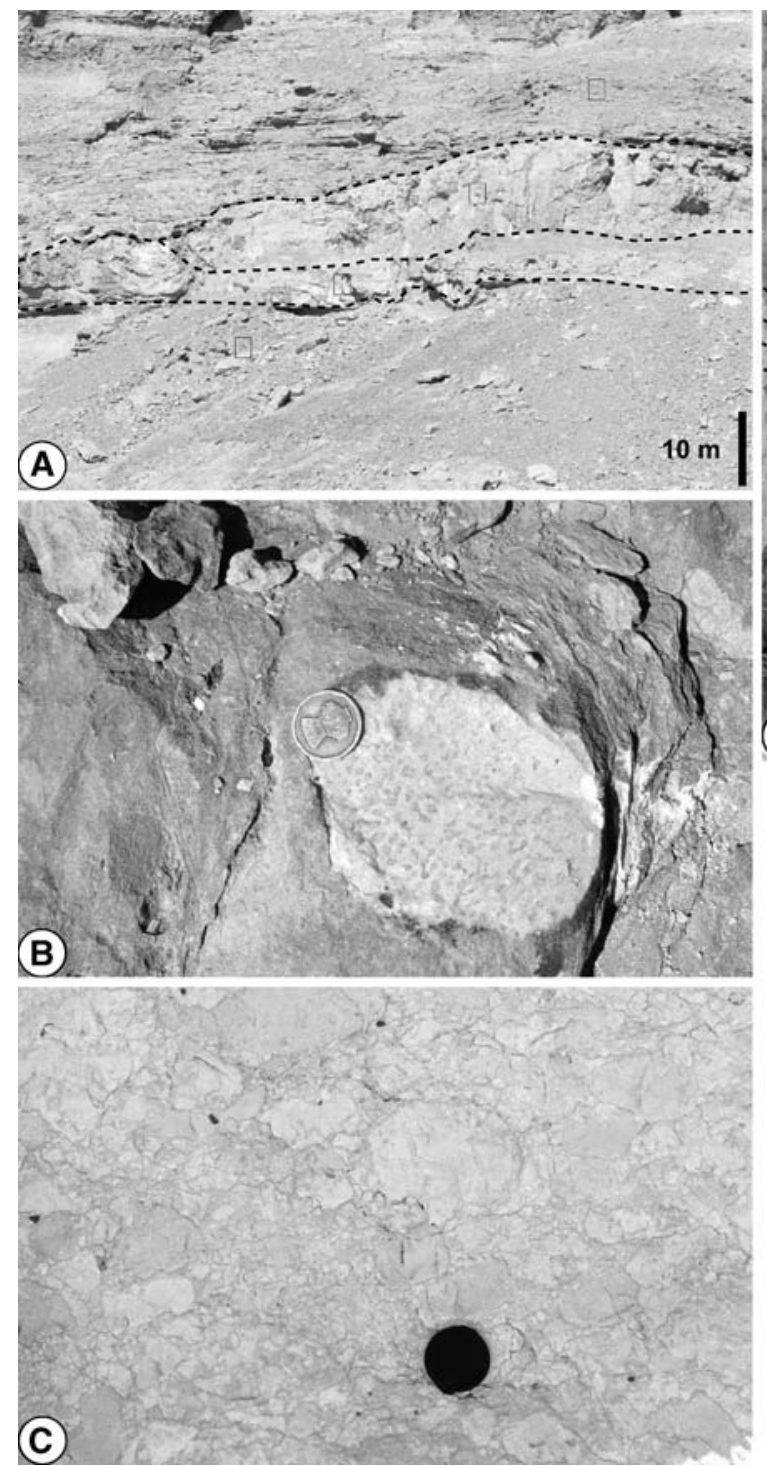

Fig. 5 Facies associations in outcrop. A Section $K 3$ a phosphatic marl facies association of the Maastrichtian and Paleocene (mostly covered by recent debris), $b$ massive-bedded limestones of the reefdebris facies association, $c$ massive lenticular shaped coral patch reef, $d$ thin-bedded limestones of the upper slope facies association. B Dendroid coral from the patch-reef association in section B2. C

B3, and in the St. Anthony and Wadi Askhar areas (Fig. 1). Both subgroups consist of decimeter to meterthick bedded carbonates, which show very little diagenetic alteration. In the first subgroup, the larger foraminifera Miscellanea spp. and coralline red algae form the dominant components with minor Glomalveolina spp., Discocyclina spp., Ranikothalia spp., corals and encrusting organisms plus rare to abundant quartz grains. The second subgroup consists predominantly of mudstone, with rare benthic and planktonic foraminifera. This facies association is deposited at the upper slope facies belt.
Reef-debris facies association in section K2. D Slump and debrisflow facies association (section D5), $a$ recent debris, $b$ hemipelagic marls, $c$ debris flows, $d$ massive slumps to debris flows. E Calciturbidites intercalated with hemipelagic marls, arrow indicates person for scale (section D2)

\section{Larger foraminifera shoal association}

The larger foraminifera shoal association (Fig. 4), is present only at section A5 (Fig. 1). It consists of up to 5$\mathrm{m}$-thick intervals with dm-thick layered limestones and contains predominantly larger foraminifera belonging to one genus or even one species. These shoals are built of Miscellanea sp. or Operculina sp. deposited in a micritic to sparitic matrix. Other components are coralline red algae, Glomalveolina spp. and Discocyclina spp. The larger foraminifera shoal association is characteristic for the younger deposits in the platform margin facies belt. 


\section{Phosphatic marl association}

The phosphatic marl association (Fig. 4), can be found in the northern part of the study area, from sections B2 and B3 to St. Anthony and Wadi Askhar (Fig. 1). It is restricted to the deposits below the patch-reef and reefdebris association. They comprise siliciclastic marls with a high phosphate content reaching their highest levels just below the base of the overlying patch-reefs or reef-debris units (Fig. 4). Abundant shark teeth, small solitary corals and mollusks occur in the upper part of this association. Planktic foraminifera and calcareous nannofossils are common within these sediments but usually are poorly preserved hampering the biostratigraphic resolution in comparison to the marls of the age-equivalent hemipelagic facies association. The phosphatic marls accumulated in the upper slope facies belt in the early to late Paleocene.

\section{Hemipelagic association}

The hemipelagic facies association (Fig. 4) characterizes the southern areas, e.g., around Bir Dakhl, where it was either deposited undisturbed in the lower Paleocene or is intercalated with calciturbidites (sections D8, D6, D2, D3, D4; Fig. 5e) or debris flows in the upper Paleocene (lower part of section D5; Fig. 5d). South of this area (sections T1 and T2; Fig. 1; Scheibner et al. 2001a) hemipelagic sediments were deposited throughout the entire Paleocene without intercalations of calciturbidites. This facies association comprises gray-green shaley marls with abundant moderate-well-preserved planktonic and smaller benthic foraminifera and calcareous nannofossils. This facies association is deposited from the lower slope to the basin facies belts.

\section{Allochthonous facies associations}

\section{Siliciclastic association}

Siliciclastic units are restricted to two isolated occurrences within sections S1-8 (Scheibner et al. 2000) and A5 (Fig. 1). In section S1-8, fine-grained quartzose sandstones with a micritic matrix occur as sheet-like bodies. They resulted from downslope transport via submarine canyons or channels (Scheibner et al. 2000). In section A5 (20-25 m) located north of section S1-8 (Fig. 1), the sandstones are coarser grained and accumulated in two lenticular-shaped bodies up to $1.5 \mathrm{~m}$ high and $3 \mathrm{~m}$ wide which, based on their larger grain size, are interpreted to be deposited in the more proximal part of a submarine canyon or channel. The siliciclastic association is found in the platform margin and in the debris-flow facies belts. Individual siliciclastic grains were deposited in all facies belts. Because of the rare occurrence of the siliciclastic facies association, it is not illustrated in any of the figures.

\section{Reef-debris association}

The reef-debris association (Figs. 4, 5a, c) is found close to the patch-reef association. Sections K2 and K3 in the Wadi Askhar provide the best examples of this facies association (Figs. 1, 5a, c). In contrast to the lenticular bodies of the patch-reef association, the reef-debris association is deposited as massive, up to 15-m-thick bedded limestones. These massive limestones comprise dm-sized clasts with partly sutured contacts or even stylolitic boundaries (Fig. 5c) and show only minor diagenetic alteration. Dendroid, meandroid and cerioid coral fragments, coralline red algae, Polystrata alba, echinoderms, gastropods, Discocyclina spp., Miscellanea spp., rotaliids, rare planktic foraminifera and in the upper parts also Glomalveolina spp. is present. Non-skeletal components include intraclasts, peloids and rare quartz grains. Reef debris has accumulated within the platform margin to the upper-slope facies belts.

\section{Debris-flow association}

The debris-flow association (Figs. 4, 5d) is exposed in sections B2, B3, the St. Anthony and Wadi Askhar areas and the northern part of the Bir Dakhl area (sections D5 and D8; Fig. 1). The debris-flow facies association shows the widest range of sedimentological structures and lithofacies with multiple transitions between glides, slumps, and debris flows, mainly comprising carbonates with only minor quartz. The debris flows vary in size and shape in both a vertical and horizontal sense, with thicknesses ranging from 0.5 to $7 \mathrm{~m}$ and width ranging from 10 to $50 \mathrm{~m}$. The debris flows have a classical convex upward shape with onlapping sediments, or are distributed sheetlike or even have a convex downward shape as if they had been deposited in singular channels. These masstransported deposits are described in greater detail in Scheibner et al. (2000), who describes a 370-m-wide outcrop that contains all the previous mentioned sedimentological structures (St. Paul S1-9; Fig. 1). The debris flows contain different types of clasts ranging in size from 1 to $50 \mathrm{~cm}$. With the exception of the hemipelagic facies association, debris of all other facies associations is present within the debris-flow association. Clasts of different associations do not occur together but are restricted to individual debris-flow units, reflecting the precise origin of that particular unit. The debris-flow association is characteristic of the lower slope facies belt.

\section{Calciturbidite association}

The main outcrops of the calciturbidite association (Figs. 4, 5e) are located in the southern Bir Dakhl area (sections D6, D2, D4, and D3; Fig. 1). Some $20 \mathrm{~km}$ further southwest of D3 in section T2 (Fig. 1; upper inlay), the calciturbidites are absent (Scheibner et al. 2001a). To the north the calciturbidite association 
interfingers with the debris-flow association. The calciturbidites facies association is composed of alternating limestones (up to $1 \mathrm{~m}$ thick) with abundant chert layers or nodules and shaley marls (up to $0.7 \mathrm{~m}$ thick), forming the normal hemipelagic background sedimentation. The calciturbidites form cliffs in the recent topography that separate the hemipelagic sediments of the underlying Dakhla Formation from the overlying Esna Formation. In section D2 the calciturbidites show abundant bioturbation including Zoophycos and Thalassinoides (Scheibner et al. 2001a). The bottom surfaces of some calciturbidites show flute casts and load casts. Most of the turbidites show fining upward trends. The calciturbidites comprise grainstones to packstones, wackestones and even mudstones with a broad variety of allochems. Some of the packstones and grainstones show sutured contacts between individual clasts and/or dissolution seams. The main bioclastic components are larger foraminifera, including Discocyclina spp., Assilina spp. and Miscellanea spp., coralline red algae, bryozoa and echinoderms. Some of the calciturbidites contain abundant well-preserved planktic foraminifera, whilst quartz grains are common to abundant in others. Other non-skeletal components include glauconite, phosphate, chert, intraclasts and rare peloids. Shallow-marine components such as corals and alveolinids, are very rare to absent. Calciturbidites are deposited in the toe-of-slope facies belt.

\section{Stages of platform evolution}

In this chapter the five different stages (A-E; Figs. 2, 3 and 6) of the Maastrichtian-Paleocene platform evolution are described. In the toe-of-slope to basin facies belts the biostratigraphic resolution is well-constrained by calcareous nannoplankton, whilst for the upper slope and platform margin the biostratigraphic resolution with larger foraminifera is less certain because of their less common occurrences. Fig. 3 summarizes the biostratigraphic information for all sections.

Stages A, B: hemipelagic to slope sedimentation

During stages A and B (Maastrichtian to late Paleocene/ 59 Ma, NP5; Fig. 6a, b), the platform margin was stationary. The main differences between both stages are different rates in sedimentation. During stage A sedimentation, rates show the greatest variability with values ranging from 2.1 to $432 \mathrm{~mm} / \mathrm{ka}$ while during stage $\mathrm{B}$ the sedimentation rates range from 0.3 to $16.1 \mathrm{~mm} / \mathrm{ka}$ (Scheibner et al. 2003).

The Maastrichtian deposits of the study area can be subdivided into basinal chalks, present in the Bir Dakhl and St. Paul areas, and siliciclastic marls and limestones of the platform slope located in sections B2 and B3, and the St. Anthony and Wadi Askhar areas in the north (stage A). Near the Cretaceous/Paleogene boundary $(\mathrm{K} / \mathrm{P})$ the basinal chalks were replaced by green-gray shaley marls, whilst on the platform slope area, Maastrichtian siliciclastic marls continue into the Paleocene (Fig. 7). The high-phosphate content (indicated by high total $\gamma$-ray counts of $20 \mathrm{cps}$ ) of the Maastrichtian platform slope sediments increased in the Paleocene (stage B) reaching values of $50 \mathrm{cps}$ just below the base of the massive limestones, comprising reef debris and/or patch reefs (Fig. 3). Shark teeth and small phosphatic concretions have been found in this upper part. Just below the coral patch reefs of stage $\mathrm{C}$, thin (max. $0.5 \mathrm{~m}$ thick) siliciclastic and phosphate-rich debris flows were deposited in the northern areas (sections A1, K2), whereas thin calciturbidites accumulated in the southern areas (section D2). The initial mass-flow deposits mainly contain abundant quartz, coralline red algae, Miscellanea spp., intraclasts and phosphate. Corals have not been found.

\section{Stage C: first progradational phase}

After the deposition of the initial debris flows, progradation of the margin initiated in stage C (late Paleocene/59 57.5 Ma, NP5-NP6; Fig. 6c), and coral patch reefs formed in the north (St. Anthony area) while at the same time, thick massive beds of reef debris accumulated further south in the Wadi Askhar area (sections K2 and K3; Figs. 1, 2, 7). In section D5 the first debris flows containing corals were deposited during this phase intercalated with hemipelagic marls. In the most southern situated areas, calciturbidites occur interbedded with hemipelagic marls (sections D2 and D3).

\section{Stage D: second progradational phase}

At the northern rim of the Southern Galala (St. Anthony area), several generations of partially overlapping patch reefs with an individual height of about $25 \mathrm{~m}$ can be identified in stage D (late Paleocene/57.5-56.2 Ma, NP78; Fig. 6d), whereas about $7 \mathrm{~km}$ southwards (section K3) they are reduced to a single patch-reef generation of a similar height (Fig. 5a) growing on top of the previous-deposited massive reef-debris units (Figs. 2, 4, 5a). These patch reefs were morphological highs extending several meters above the seafloor with sediments onlapping them, as can be observed in section K3b (Fig. 5a). Between these patch reefs, limestones of the upper slope association were deposited (section K3c). Parallel to the area of patch-reef growth, a southward directed debris apron can be found (section K2), whilst in section D5 massive up to 15-m-high slumps to debris flows are deposited (Fig. 2). Further south, massive calciturbidites with coarse-grained components were deposited simultaneously in facies dominated by hemipelagic sediments (sections D6, D8, D2, D3 and D4). The smaller benthic foraminifera found in these hemipelagic sediments evidence a depositional depth of about 400 $500 \mathrm{~m}$. Abundant chert layers and nodules occur in the calciturbidites (Fig. 2). A similar but weaker siliceous overprint is visible in the debris flows of section D5. 
Fig. 6 Evolution of the Paleocene carbonate platform of the southern Galala. The siliciclastic facies association is not shown because of its limited extent
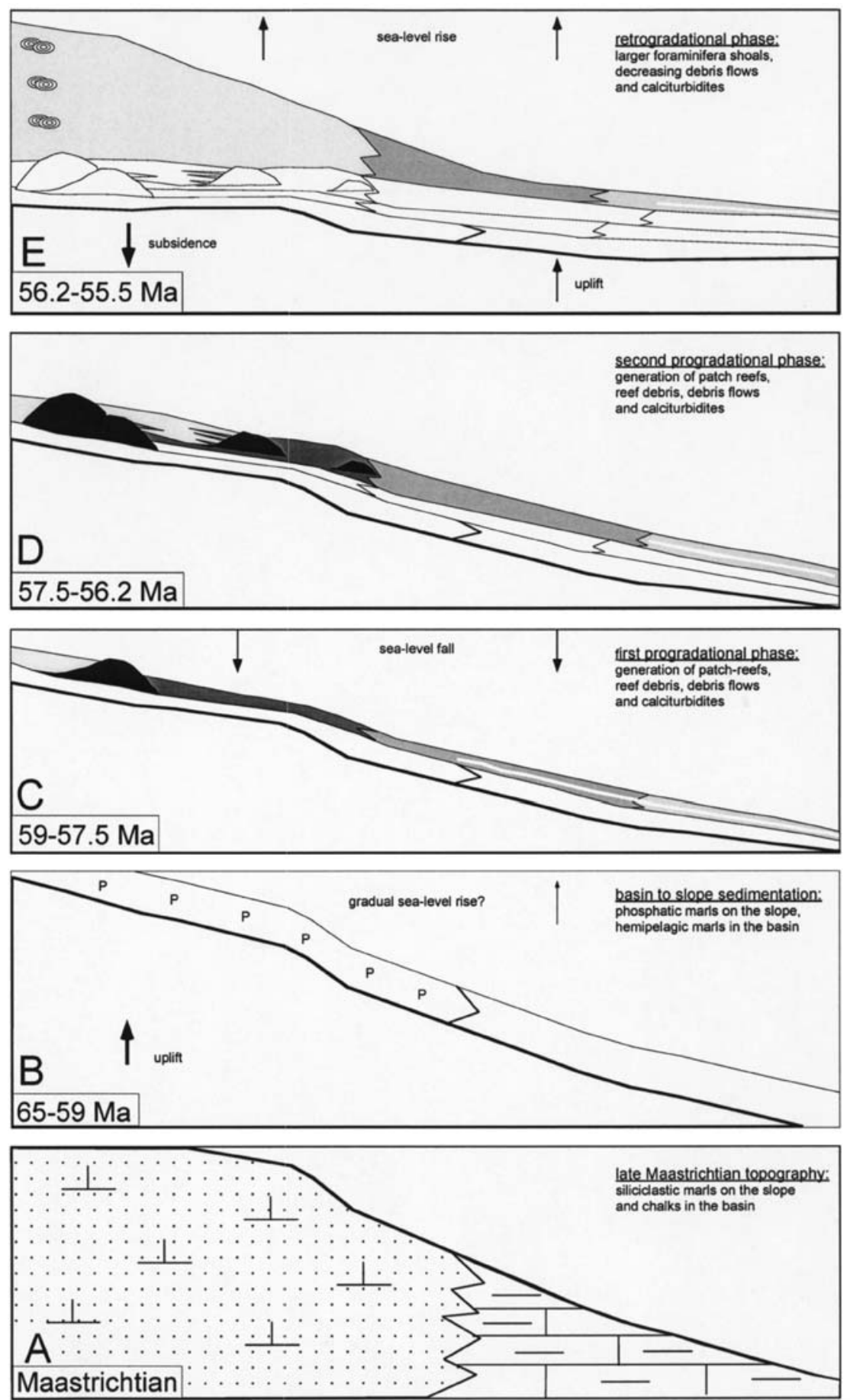

\begin{tabular}{|c|c|c|c|c|c|}
\hline Facies associations (Paleoce & & & & & Lithology (Maastrichtian): \\
\hline patch reef & & calciturbidite and hemipelagic & $\mathbf{P}$ & phosphatic marls & . $\downarrow$. siliciclastic marls \\
\hline reef debris & & upper slope & & hemipelagic & $\perp$ chalk \\
\hline slump and debris flow & (1) & larger foraminfera shoal & & & \\
\hline
\end{tabular}

Stage E: retrogradational phase

At this time (stage E: retrogradational phase; latest Paleocene/56.2-55.5 Ma, NP9; Fig. 6e) the limestones of the upper slope facies association covered the patch reefs and reef debris in the northern areas (section A5, K3 and K2; Figs. 4, 7), indicating a retrogradational episode of the margin. In section D5, the mass-flow deposits changed from debris flows to slumps (Fig. 2), while in the southern areas the particle size within the individual 
Fig. 7 Paleogeographic maps for three distinct calcareous nannofossil zonations during the Paleocene. 65-59 Ma correlates approximately with NP1-NP5 and SBZ1-2. 5956.2 Ma correlates approximately with NP5-NP7/8 and SBZ3. 56.2-55.5 Ma correlates approximately with NP9 and SBZ4. For detailed correlations see Fig. 3. The basin facies belt is not represented in the two younger plots because it occurs south of the toe-of-slope facies belt
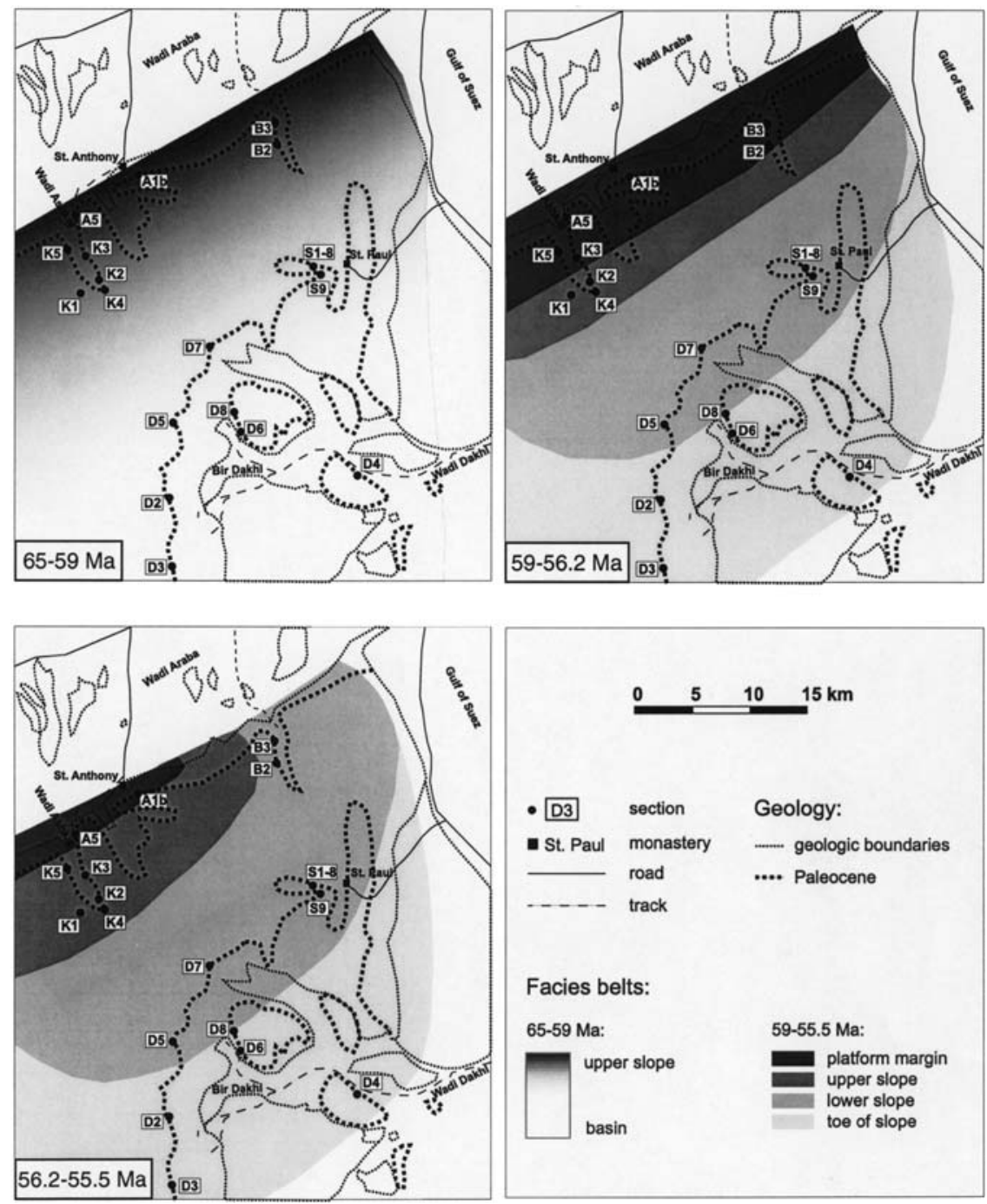

calciturbidites decreased. The content of these calciturbidites changed to a dominance of planktic foraminifera with only rare shallow-marine components (sections D2, D3 and D4). During this interval the sandstone facies association was deposited in section A5. This latest phase in platform evolution is characterized by increased sedimentation up to $80 \mathrm{~m}$ in the platform margin to upper slope facies belt (sections A5, K3b). In contrast only $15 \mathrm{~m}$ of hemipelagic sediments and calciturbidites are deposited in the lower slope to toe-of-slope facies belt (sections D5, D8, D6). The smaller benthic foraminifera found in sections D6 and D8 indicate a depositional depth of about $200 \mathrm{~m}$. In the most proximal section A5, deposits of the larger foraminiferal shoal association occur intercalated between sediments of the upper-slope facies association, whereas section $\mathrm{K} 3 \mathrm{~b}$ is characterized by the monotonous upper-slope facies association.

\section{Discussion}

Evolution of the carbonate platform

\section{Stages A, B: hemipelagic to slope sedimentation}

The enrichment in phosphate (Maastrichtian-late Paleocene/59 Ma, NP5; Fig. 6a, b) is due to reworking or eutrophication (e.g., Kennett 1992) related to local upwelling, which was present from the Maastrichtian onwards and increased during the late Paleocene.

The mixture of skeletal and non-skeletal debris in the initial late Paleocene debris flows probably resulted from lowered relative sea-level during which organisms from the exposed platform (lying in the areas of today Wadi Araba) were shed and mixed with reworked particles from the platform margin/platform slope. Due to reworking of the underlying phosphatic siliciclastic marls, these calcareous mass-flow deposits show higher than normal total $\gamma$-ray counts $(10-15 \mathrm{cps}$ in contrast to $5-8 \mathrm{cps})$. 


\section{Stage C: first progradational phase}

It remains unclear whether the coral patch reefs in the study area during stage $\mathrm{C}$ (late Paleocene/59-57.5 Ma; NP5-NP6; Fig. 6c) shifted southwards due to a relative sea-level fall or they were a new facies association at the platform margin in the region. It may be impossible to solve this question since erosion has removed most of the Mesozoic and Cenozoic sediments north of the studied patch reefs (area of today's Wadi Araba).

Previous studies (Kulbrok 1996; Gietl 1998; Scheibner et al. 2000) suggested the existence of coral patch reefs in the late Paleocene, because of the presence of coral debris in the sediments of the Southern Galala, but did not present evidence for the existence of in-situ patch reefs.

Reefs debris was transported southwards as semilithified clasts. Because of the low upper-slope inclination angle of less than $1^{\circ}$ (Scheibner et al. 2001b) on which the patch reefs grew, no high-speed debris-flow deposits were initiated and the sediments moved downslope by gradual creep. Under normal depositional conditions, this type of coarse-grained sediment would not be transported, as it was deposited below the critical angle of repose for such sediments (Kenter and Schlager 1989; Kenter 1990) and should therefore be regarded as stable. A possible mechanism for transporting sediments on a slope with an angle of repose below the critical threshold angle could be through tectonic activity. According to Strougo (1986), the late Paleocene was a time of increasing tectonic activity in Egypt. The relative sea-level fall that initiated the progradation of the platform was probably caused by a combination of tectonic activity (uplift of the Northern Galala/Wadi Araba High; Kuss et al. 2000b) and a eustatic sea-level fall during the Selandian of approximately $100 \mathrm{~m}$ (sequence TA 2.1 of Haq et al. 1987 and Hardenbol et al. 1998). The deposition of slumps and debris flows started south of the former shelf break where the slope reaches inclinations of about $5-8^{\circ}$ (Scheibner et al. 2001a). In the subhorizontal toe-of-slope areas the angles were too low to support further transport of the debris flows and they came to an abrupt stop (Middleton and Hampton 1976; Einsele 2000). On their way downslope these debris flows probably initiated calciturbidites that accumulated at the toe of slope (sections D6, D2, D4 and D3). Einsele (1991) described the general outline of this process, while Blomeier and Reijmer (2002) described a similar process for platform margin deposits from the Jurassic in Morocco. Hemipelagic sediments present between the debris-flow deposits enabled the recognition of three pulses within the overall progradational trend (Scheibner et al. 2000).

\section{Stage D: second progradational phase}

The single generation patch reefs at the platform margin south of section A5 (section K3 and south of section K2; Fig. 4) were initiated during Stage D (late Paleocene/ 57.5-56.2 Ma, NP7-8; Fig. 6c) as soon as the water depth in these areas decreased due to infill of accommodation space during the deposition of reef-debris deposits from the north bringing the sediment surface into water depths favorable for patch-reef growth. Coral branches or buds transported to these locations probably enabled the growth of these southern patch reefs and ultimately resulted into a southward shift of the platform margin.

During the time the patch reefs and shallow-marine limestones were deposited in the northern areas, sediment was transported as slumps and debris flows on the lower slope that now acted as a depocenter for these sediments. In the Triassic carbonate platform of the Dürrenstein (Dolomites), slumps and debris flows occurred in the prograding part, indicating large-scale slope failure (Biddle et al. 1992; Reijmer 1998). At the toe of slope, the deposition of calciturbidites continued. Due to the deposition of slumps and debris flows on the lower slope, the slope was leveled up and the former shelf break was shifted southwards resulting in the progradation of the carbonate platform.

\section{Stage E: retrogradational phase}

During the time spanning the lower SBZ 4 (stage E: latest Paleocene/56.2-55.5 Ma, NP9; Fig. 6e), the patch-reef association in sections $\mathrm{A} 5$ and $\mathrm{K} 3 \mathrm{~b}$ and the reef-debris association in section $\mathrm{K} 2$ was superseded by muddominated lithologies of the upper slope facies association. These mud-dominated lithologies represent a landward shift of the facies belts and resulted from either a rise in sea level, a modification in tectonic activity or a combination of both which caused platform retrogradation. A similar mud-dominated interval has been described for the retrogradational phase of the Dürrenstein carbonate platform (Reijmer 1998). The rise in relative sea level led to the decline of the patch reefs in sections K3 and A5. The patch-reef association probably shifted for a short time period to a more northerly position, since on top of the patch reefs in section A5 $(20-30 \mathrm{~m})$, coral fragments still occur. As the platform margin retrograded northwards to the area of section A5, larger foraminiferal shoals were deposited at the position of the former coral patch reefs and for the upper interval $(30-120 \mathrm{~m})$ even fragments of corals are completely absent. Changing environmental factors could have resulted in different depositional regimes which in turn may be the reason why coral patch reefs became rarer and disappeared in the late Paleocene. During the relative sea-level rise around $56 \mathrm{Ma}$ (NP9, within SBZ4), the platform progradation terminated, which is also evidenced by a decrease in slump and debris-flow deposits on the lower slope and by a decrease in the amount of calciturbidites arriving at the toe-of-slope.

This platform retrogradation was probably more related to tectonically induced subsidence than to an eustatic sea-level rise, since high sedimentation rates in the northern sections A5 and K3b without contemporaneous southward progradation suggest an increase in subsidence 
in these areas. Simultaneously, the water depth in the Bir Dakhl area (sections D6, D8) decreased as indicated by changing smaller benthic foraminifera associations. A mixture of Midway and Velasco-type taxa (e.g., Speijer 1994) indicate depositional depths of about $400-500 \mathrm{~m}$, whereas benthic assemblages entirely composed of Midway-type taxa indicate shallower depositional depths of about $200 \mathrm{~m}$.

The differences in subsidence can be explained by rotational movement along a listric fault located at the northern rim of the Southern Galala (Wadi Araba Fault; Figs. 1, 8). This type of fault-related movement and thus creation of reduction in accommodation space in such half grabens, result in hangingwall subsidence (and relative sea-level rise) synchronous with footwall uplift and a relative sea-level fall (Bosence 1998; Bosence et al. 1998; Cross et al. 1998). The varying siliciclastic content in all sections in the upper Paleocene suggest tectonic uplift and subsequent erosion in the footwall sediments lying north of the Wadi Araba Fault. Sharp et al. (2000) and Young et al. (2002) documented a similar tectonosedimentary evolution from the eastern side of the Gulf of Suez. Their three-dimensional stratigraphic structures present in the syn-rift models agree well with the largescale distribution patterns found in our study.

In contrast to the symmetrical uplift during the first progradation phase, the retrogradational phase is marked with differential subsidence, which is evident in the varying distribution of the individual facies belts (Fig. 7). In section A5 the platform margin facies belt with larger foraminiferal shoals is present, whilst in sections B2 and B3, the lower slope facies belt with slumps and debris flows dominates; although, during the first progradation phase, all three sections belonged to the platform margin facies belt.

Carbonate slope development: sea level versus tectonics

The main controls for progradation and retrogradation of carbonate platforms are eustatic sea-level changes and tectonic activity (Bosellini 1984; Everts 1991). Progradation can take place only when the accommodation space available on the slope has been filled (e.g., Reijmer 1998). In contrast to siliciclastic systems where most sediments were exported during sea-level lowstands (e.g., Jervey 1988), in carbonate systems export occurs mostly during sea-level highstands (Droxler and Schlager 1985 and Schlager et al. 1994).

Sediment export and the lateral growth potential of a carbonate platform is controlled by a large number of factors, e.g., platform/basin profile, bank-margin type, accommodation space, sea-level variations, climate, supply of terrigenous material, as well as the duration, magnitude and direction of physical energy (e.g., currents, tides) on the platform and adjacent seaways (e.g., Eberli and Ginsburg 1989; Pittet 1996; Rendle and Reijmer 2002).
$-\mathrm{N}-$ -s-
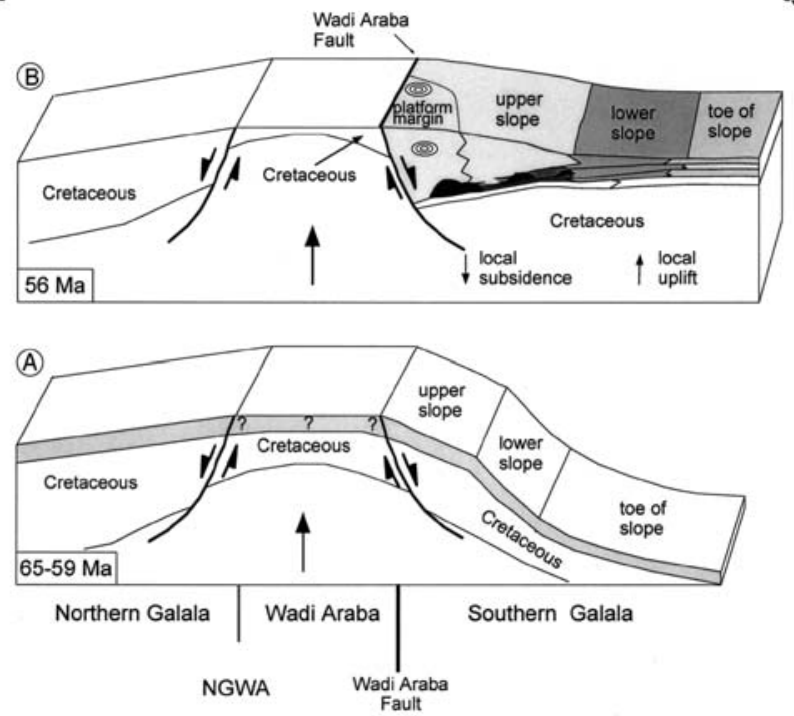

Fig. 8 Tectono-sedimentary evolution of the platform margin to toe-of-slope deposits in the southern Galala. The main fault dividing the Wadi Araba from the southern Galala is the Wadi Araba Fault. The tectonic movements on the Northern Galala are hypothetical. The basin facies belt is not represented because it lies south of the toe-of-slope facies belt A Tectono-sedimentary situation for the Danian to Selandian (65-59 Ma). Whether the carbonate platform was completely covered with sediments remains uncertain. B Tectono-sedimentary situation for the Thanetian (56 Ma). Rotational block movements along the Wadi Araba Fault resulted in local subsidence at the carbonate platform margin and upper slope areas, and local uplift in the lower slope to toe-of-slope settings

The sedimentation pattern observed in the subsurface geology of the Bahamas suggests that progradation is controlled by production of the platform interior, which is influenced by many factors, e.g., eustatic sea-level changes, currents, subsidence (e.g., Wilber et al. 1990; Eberli et al. 1997, 2001; for an overview see Schlager 1993). Two types of progradation were proposed for the Triassic platforms in the Southern Alps (Bosellini 1989; Masetti et al. 1991). Progradation related to redeposition of carbonate mud and sand previously accumulated at the platform edge during sea-level highstands, or progradation occurred during sea-level lowstands in which subaerial exposure and increased erosion of the lithified platform top produced enough sediments to enable the system to prograde (Masetti et al. 1991). The progradation of the Cassian and the Carnian platforms in the Dolomites are seen as representative for lowstand progradation (Bosellini 1984, 1989; Masetti et al. 1991). Sarg (1988), however, describes the Carnian carbonate platforms as a typical example for progradation during the late highstand. Reijmer (1998) showed that input from the shallow-water realm of the Picco di Vallandro/Dürrenstein (Dolomites/Italy) platform steered the toe-of-slope sediments to step forwards towards the basin or to retreat.

Recent studies on the Paleocene sea-level history of Sinai (Lüning et al. 1998) suggest a major sea-level drop at the base of P4 (within NP5) and subsequent minor sea- 
level oscillations during P4. This major sea-level drop coincides with an approximately 100-m-sea-level drop in the curve of Haq et al. (1987). Speijer and Schmitz (1998) also suggested a sea-level drop during lower P4 based on studies of benthic foraminifera from Gebel Aweina (ca. $300 \mathrm{~km}$ to the south), matching Th1 of Hardenbol et al. (1998). However, local tectonics can not be excluded as an additional factor lowering relative sea level, especially as the detached carbonate platform in the Galalas is located on a tectonically induced high of the Syrian Arc System (Kuss et al. 2000b). Strougo (1986) reported late Paleocene tectonic activity in several parts of Egypt and called it the Velascoensis event, after the planktic foraminiferal species Morozovella velascoensis, whose stratigraphic range is nearly coincident with the P4 and P5 Zones. One of his examples for tectonic activity was the debris-flow deposit in the vicinity of monastery St. Paul (Fig. 1). The interval of P4-P5 correlates with the stratigraphic interval from NP5-NP9. Thus, the onset of patch-reef formation and the mass-flow deposition on the detached carbonate platform in the study area was probably due to a combination of a large fall in eustatic sea level within biozone NP5 (Scheibner et al. 2000) and local tectonic uplift (Strougo 1986). This shows that tectonic activity may dominate over normal sea-level steered sedimentation patterns like highstand shedding (Schlager et al. 1994), which was also documented by Cloetingh et al. (1985) and Miall (1990).

The retrogradation phase could not be explained exclusively by a rise in eustatic sea level because of the high sedimentation rates of the northern sections (A5, $\mathrm{K} 3 \mathrm{~b}$ ), and the relative sea-level fall in the southern sections (sections D6, D8). The varying siliciclastic content in all sections also document tectonic activity in the hinterland. The rising relative sea level at the platform margin contrasts with the relative sea-level fall in the toe of slope (sections D6 and D8). This contrast can be explained by rotational block movements (Fig. 8). Therefore tectonic activity was not only responsible for the progradation, but also for the retrogradation of the Paleocene carbonate platform. The initial progradation of the Paleocene carbonate platform was due to an uplift of the NGWA, whereas the retrogradation can be related to fault block rotation (Fig. 8). Similar to our findings, Schütz (1994) stated that tectonic activity and high subsidence rates, as well as high carbonate production in areas forming the now Wadi Araba, allowed the thick Eocene carbonate accumulation around the high, and thus this area serves as a well-documented case of sedimentation controlled by tectonics.

\section{Conclusions}

In conclusion, it can be stated that the evolution of the Paleocene carbonate platform margin and the variation of the biotic content along the Southern Galala Mountains (Egypt) is closely related to tectonic activity (varying processes and amounts of uplift and subsidence) instead of eustatic sea-level changes. The following five tectonosedimentary stages characterize the evolution of the Paleocene carbonate platform:

- Maastrichtian (stage A) to Selandian (stage B) seabed bottom topography controlled the initial lateral facies distribution (stage C) across the platform-basin transect.

- The combination of a significant drop in sea level and tectonic uplift of the Northern Galala/Wadi Araba High initiated the late Paleocene platform progradation (stage C) in the Selandian (59 Ma).

- During the progradation phases of the carbonate platform (stages C and D; 59-56.2 Ma; NP5-NP8) the following facies belts developed: coral patch reefs, and reef debris were deposited at the platform margin, well-bedded carbonates on the upper slope, slumps and debris flows on the lower slope, calciturbidites at the toe of slope and hemipelagic sediments in the basin.

- During the retrogradational phase (stage E; 56.2$55.5 \mathrm{Ma}$; NP9), the combination of a sea-level rise and differentiated subsidence of various parts of the platform due to rotational block movements, not only resulted in a change of organisms at the platform margin from coral patch reefs to larger foraminiferal shoals, but also in a decrease in slump and debris-flow activity on the lower slope, and a decrease in calciturbidite activity at the toe of slope.

Acknowledgements Prof. A.M. Bassiouni and Dr. A.M. Morsi (both from Ain Shams University) are thanked for their continuous support during our field campaigns in Egypt. Christian Müller is thanked for his help during the field trip in autumn 2001. We thank Andrew Racey, Conxita Taberner, Dan Bosence and Maria Mutti for their constructive reviews. This project was funded by the German Science Foundation (DFG-KU 642/19-1).

\section{References}

Adams EW, Schlager W, Wattel E (1998) Submarine slopes with an exponential curvature. Sediment Geol 117:135-141

Adams EW, Schlager W (2000) Basic types of submarine slope curvature. J Sediment Res 70:814-828

Andresen N, Reijmer, JJG Droxler, AW (2003) Timing and distribution of calciturbidites around a deeply submerged carbonate platform (Pedro Bank, northern Nicaragua Rise, Caribbean Sea). Int J Earth Sci 10.1007/s00531-003-0340-0

Bandel K, Kuss J (1987) Depositional environment of the pre-rift sediments: Galala Heights (Gulf of Suez, Egypt). Berliner Geowiss Abh A 78:1-48

Beattie PD, Dade WB (1996) Is scaling in turbidite deposition consistent with forcing by earthquakes? J Sediment Res 66:909-915

Berggren WA, Kent DV, Swisher III CC, Aubry MP (1995) A revised Cenozoic geochronology and chronostratigraphy. In: Berggren WA, Kent DV, Aubry MP, Hardenbol J (eds) Geochronolgy, time scales, and global stratigraphic correlation, SEPM Spec Publ No 54, Society for Sedimentary Geology, Tulsa, Oklahoma, pp 129-212

Berggren WA, Aubry MP, van Fossen M, Kent DV, Norris RD, Quillévéré F (2000) Integrated Paleocene calcareous plankton magnetobiochronology and stable isotope stratigraphy: DSDP Site 384 (NW Atlantic Ocean). Palaeogeogr Palaeoclimatol Palaeoecol 159:1-51 
Biddle KT, Schlager W, Rudolph KW, Bush TL (1992) Seismic model of a progradation carbonate platform, Picco di Vallandro, Dolomite Alps, northern Italy. Am Assoc Petrol Geol Bull 76:14-30

Blendinger W (2001) Triassic carbonate buildup flanks in the Dolmites, northern Italy: breccias, boulder fabric and the importance of early diagenesis. Sedimentology 48:919-933

Blomeier D, Reijmer JJG (2002) Facies architecture of a Lower Jurassic carbonate platform slope (Jbel Bou Dahar, High Atlas, Morocco). J Sediment Res 72:463-476

Bosellini A (1984) Progradation geometries of carbonate platforms: examples from the Triassic of the Dolomites, Italy. Sedimentology 31:1-24

Bosellini A (1989) Dynamics of Tethyan carbonate platforms. In: Crevello PD, Wilson JL, Sarg JF, Read JF (eds) Controls on carbonate platform and basin development. Special Publ No 44. Society of Economic Paleontologists and Mineralogists, Tulsa, Oklahoma, pp 3-13

Bosence DWJ (1998) Stratigraphic and sedimentological models of rift basins. In: Purser BH, Bosence DWJ (eds) Sedimentation and tectonics of rift basins: Red Sea-Gulf of Aden. Chapman and Hall, London, pp 9-25

Bosence D, Cross N, Hardy S (1998) Architecture and depositional sequences of Tertiary fault-block carbonate platforms: an analysis from outcrop (Miocene, Gulf of Suez) and computer modeling. Mar Petrol Geol 15:203-221

Burgess PM (2001) Modeling carbonate sequence development without relative sea-level oscillations. Geology 29:1127-1130

Cloetingh S, McQueen H, Lambeck K (1985) On a tectonic mechanism for regional sea level variations. Earth Planet Sci Lett 75:157-166

Cross NE, Purser BH, Bosence DWJ (1998) The tectono-sedimentary evolution of a rift margin carbonate platform: Abu Shaar, Gulf of Suez, Egypt. In: Purser BH, Bosence DWJ (eds) Sedimentation and tectonics of rift basins: Red Sea-Gulf of Aden, Chapman and Hall, London, pp 271-295

Culver SJ (1993) Foraminifera. In: Lipps JH (ed) Fossil prokaryotes and protists. Blackwell, Oxford, pp 203-247

Droxler AW, Schlager W (1985) Glacial versus interglacial sedimentation rates and turbidite frequency in the Bahamas. Geology 13:799-802

Drzewiecki PA, Simo JA (2002) Depositional processes, triggering mechanisms and sediment composition of carbonate gravity flow deposits: examples from the Late Cretaceous of the southcentral Pyrenees, Spain. Sediment Geol 146:155-189

Eberli GP, Ginsburg RN (1989) Cenozoic progradation of northwestern Great Bahama Bank, a record of lateral platform growth and sea-level fluctuations. In: Crevello PD, Wilson JL, Sarg JF, Read JF (eds) Controls on carbonate platform and basin development, Special Publ. No 44. Society of Economic Paleontologists and Mineralogists, Tulsa, Oklahoma, pp 339351

Eberli GP, Swart PK, Malone MJ, et al. (1997) Proc ocean drilling program, Initial Reports. No 166, Ocean Drilling Program, College Station, Texas, pp. 1-850

Eberli GP, Anselmetti FS, Kenter JAM, McNeill DF, Melim LA (2001) Calibration of seismic sequence stratigraphy with cores and logs. In: Ginsburg RN (ed) Subsurface geology of a prograding carbonate platform margin, Great Bahama Bank: results of the Bahamas Drilling Project. SEPM (Society for Sedimentary Geology) Spec Publ No 70, Tulsa, Oklahoma, pp 241-265

Einsele G (1991) Submarine mass-flow deposits and turbidites. In: Einsele G, Ricken W, Seilacher A (eds) Cycles and events in stratigraphy. Springer, Berlin Heidelberg New York, pp 313339

Einsele G (2000) Sedimentary basins. Springer, Berlin Heidelberg New York, 792 pp

Everts AJW (1991) Interpreting compositional variations of calciturbidites in relation to platform-stratigraphy: an example from the Paleogene of SE Spain. Sediment Geol 71:231-242
Gietl R (1998) Biostratigraphie und Sedimentationsmuster einer nordostägyptischen Karbonatrampe unter Berücksichtigung der Alveolinen-Faunen. Ber Fachbereich Geowiss Univ Bremen 112:1-135

Haq BU, Hardenbol J, Vail P (1987) Chronology of fluctuating sea levels since the Triassic. Science 235:1156-1167

Hardenbol J, Thierry H, Farley MB, Jacquin T, De Graciansky P, Vail PR (1998) Mesozoic and Cenozoic sequence chronostratigraphic framework of European basins. In: de Graciansky PC, Hardenbol J, Jacquin T, Vail PR (eds) Mesozoic and Cenozoic sequence stratigraphy of European basins. SEPM Spec. Publ No 60. Society for Sedimentary Geologists, Tulsa, Oklahoma, pp 3-13

Hussein IM, Abd-Allah AMA (2001) Tectonic evolution of the northeastern part of the African continental margin, Egypt. J Afr Earth Sci 33:49-68

Jervey MT (1988) Quantitative geological modeling of siliciclastic rock sequences and their seismic expression. In: Wilgus $\mathrm{CK}$, Hastings BS, Kendall CGSC, Posamentier HW, Ross CA (eds) Sea-level changes: an integrated approach, SEPM Spec Publ No 42. Tulsa, Oklahoma, pp 47-69

Keim L, Schlager W (2001) Quantitative compositional analysis of a Triassic carbonate platform (Southern Alps, Italy). Sediment Geol 139:261-284

Kennett JP (1982) Marine geology. Prentice Hall, Englewood Cliffs, New Jersey, pp 1-813

Kenter JAM, Schlager W (1989) A comparison of shear strength in calcareous and siliciclastic marine sediments. Mar Geol $88: 145-152$

Kenter JAM (1990) Carbonate flanks: slope angles and sediment fabric. Sedimentology 37:777-794

Kenter JAM, Campbell AE (1991) Sedimentation on a Jurassic carbonate platform flank: geometry, sediment fabric and related depositional structures (Djebel Bou Dahar, High Atlas Morocco). Sediment Geol 72:1-34

Kulbrok F (1996) Biostratigraphie, Fazies und Sequenzstratigraphie einer Karbonatrampe in den Schichten der Oberkreide und des Alttertiärs Nordost-Äyptens (Eastern Desert, NGolf von Suez, Sinai). Berichte aus dem Fachbereich Geowissenschaften der Universität Bremen 81:216

Kuss J, Westerhold T, Groß U, Bauer J, Lüning S (2000a) Mapping of Late Cretaceous stratigraphic sequences along a Syrian Arc Uplift: examples from the Areif el Naqa/Eastern Sinai. Middle East Research Center, Ain Shams University, Earth Sci Serv 14:171-191

Kuss J, Scheibner C, Gietl R (2000b) Carbonate platform to basin transition along an Upper Cretaceous to Lower Tertiary Syrian arc uplift, Galala Plateaus, Eastern Desert, Egypt. GeoArabia 5:405-424

Lebreiro SM, McCave IN, Weaver PPE (1997) Late Quaternary turbidite emplacement on the Horseshoe abyssal plain (Iberian margin). J Sediment Res 67:856-870

Lüning S, Marzouk AM, Kuss J (1998) The Paleocene of central East Sinai, Egypt: "sequence stratigraphy" in monotonous hemipelagites. J Foramin Res 28:19-39

Martini E (1971) Standard Tertiary and Quaternary calcareous nannoplankton zonation. In: Farinacci A (eds) Proceedings of the II plankton conference, Roma. Edizioni Tecnoscienza Rome, Roma, pp 739-785

Marzouk AM, Scheibner C (2003) Calcareous nannofossil biostratigraphy and paleoenvironment of the late CretaceousPaleogene of the Galala Mountains, Eastern Desert, Egypt. Courier Forschungsinstitut Senckenberg (in press)

Masetti D, Neri C, Bosellini A (1991) Deep-water asymmetric cycles and progradation of carbonate platforms governed by high-frequency eustatic oscillations (Triassic of the Dolomites, Italy). Geology 19:336-339

AD Miall (1990) Principles of sedimentary basin analysis. Springer, New York, Berlin, Heidelberg, pp 1-668

Middleton GV, Hampton MA (1976) Subaqueous sediment transport and deposition by sediment gravity flows. In: Stanley DJ, 
Swift DJP (eds) Marine sediment transport and environmental management. Wiley, New York, pp 197-218

Moustafa AR, Khalil MH (1995) Superposed deformation in the northern Suez Rift, Egypt: relevance to hydrocarbons exploration. J Petrol Geol 18:245-266

Pittet B (1996) Controles climatiques, eustatiques et tectoniques sur des systèmes mixtes carbonates-siliciclastiques de plate-forme: exemples de 1Oxfordien (Jura suisse, Normandie, Espagne). $\mathrm{PhD}$ Thesis, Université de Fribourg, pp 1-258

Plaziat JC, Purser BH (1998) The tectonic significance of seismic sedimentary deformations within. In: Purser BH, Bosence DWJ (eds) Sedimentation and tectonics of rift basins: Red Sea-Gulf of Aden. Chapman and Hall, London, pp 347-366

Pomar L (2001) Types of carbonate platforms: a genetic approach. Basin Res 13:313-334

Prior DB, Coleman JM (1984) Submarine slope instability. In: Brunsden D, Prior DB (eds) Slope instability. Wiley, New York, pp 419-455

Purser BH, Plaziat JC (1998) Miocene periplatform slope sedimentation in the northwestern Red Sea Rift, Egypt. In: Purser $\mathrm{BH}$, Bosence DWJ (eds) Sedimentation and tectonics of rift basins: Red Sea-Gulf of Aden. Chapman and Hall, London, pp 320-346

Read JF (1985) Carbonate platform facies models. AAPG Bull 69:1-21

Reijmer JJG (1998) Compositional variations during phases of progradation and retrogradation of a Triassic carbonate platform (Picco di Vallandro/Dürrenstein, Dolomites, Italy). Geol Rundsch 87:436-448

Rendle RH, Reijmer JJG (2002) Evolutionary slope development on the western, leeward margin of Great Bahama Bank during the Quaternary. Mar Geol 185:143-164

Sarg JF (1988) Carbonate sequence stratigraphy. In: Wilgus CK, Hastings BS, Kendall CGSC, Posamentier HW, Ross CA et al. (eds) Sea-level changes: an integrated approach. Spec Publ No 42, Society of Economic Paleontologists and Mineralogists, Tulsa, Oklahoma, pp 155-182

Scheibner C, Kuss J, Marzouk AM (2000) Slope sediments of a Paleocene ramp-to-basin transition in NE Egypt. Int J Earth Sci 88:708-724

Scheibner C, Marzouk AM, Kuss J (2001a) Maastrichtian-Early Eocene litho-biostratigraphy and palaeogeography of the northern Gulf of Suez region, Egypt. J Afr Earth Sci 32:223255
Scheibner C, Marzouk AM, Kuss J (2001b) Shelf architectures of an isolated Late Cretaceous carbonate platform margin, Galala Mountains (Eastern Desert, Egypt). Sediment Geol 145:23-43

Scheibner C, Kuss J, Speijer RP (2003) Stratigraphic modelling of carbonate platform-to-basin sediments (Maastrichtian to Paleocene) in the Eastern Desert, Egypt. Palaeogeogr Palaeoclimatol Palaeoecol (in press)

Schlager W (1993) Accommodation and supply: a dual control on stratigraphic sequences. Sediment Geol 86:111-136

Schlager W, Reijmer JJG, Droxler A (1994) Highstand shedding of carbonate platforms. J Sediment Res B 64:270-281

Schütz KI (1994) Structure and stratigraphy of the Gulf of Suez, Egypt. In: Landon SM (ed) Interior rift basins. AAPG, Memoir 59, Tulsa, Oklahoma, pp 57-96

Serra-Kiel J, Hottinger L, Caus E, Drobne K, Ferrandez C, Jauhri AK, Less G, Pavlovec R, Pignatti J, Samso JM, Schaub H, Sirel E, Strougo A, Tambareau Y, Tosquella J, Zakrevskaya E (1998) Larger foraminiferal biostratigraphy of the Tethyan Paleocene and Eocene. Bull Soc Géol Fr 169:281-299

Sharp IR, Gawthorpe RL, Armstrong B, Underhill JR (2000) Propagation history and passive rotation of mesoscale normal faults: implications for syn-rift stratigraphic development. Basin Res 12:285-305

Speijer RP (1994) The late Paleocene benthic foraminiferal extinction as observed in the Middle East. Bull Soc Belge Géol 103:267-280

Speijer RP, Schmitz B (1998) A benthic foraminiferal record of Paleocene sea level and trophic/redox conditions at Gebel Aweina, Egypt. Palaeogeogr Palaeoclimatol Palaeoecol 137:79-101

Stafleu J, Schlager W (1995) Pseudo-unconformities in seismic models of large outcrops. Geol Rundsch 84:761-769

Strougo A (1986) The Velascoensis Event: a significant episode of tectonic activity in the Egyptian Paleogene. Neues Jahrb Geol Paläontol Abh 173:253-269

Wilber RJ, Milliman JD, Halley RB (1990) Accumulation of banktop sediment on the western slope of Great Bahama Bank: rapid progradation of a carbonate megabank. Geology 18:970-974

Young MJ, Gawthorpe RL, Sharp IR (2002) Architecture and evolution of syn-rift clastic depositional systems towards the tip of a major fault segment, Suez Rift, Egypt. Basin Res 14:1-23 